The taxation of accumulated income in the Frizzell situation, then, would be consistent with the treatment of similar accretions to similar transfers; it would further the statutory purpose of taxing the donor "as if" he had never made the transfer; and its possible prospective effects on the establishment of such accumulations would be in harmony with the operation and broad purposes of the estate tax as a whole.

\title{
CONSTITUTIONAL PROTECTION AGAINST FOREIGN DECREES CONFISCATING ASSETS IN THE UNITED STATES;
}

Friendly aliens ${ }^{1}$ owning assets in this country have frequently relied upon our courts to protect that property from confiscation ${ }^{2}$ by their own or other governments. ${ }^{3}$ When granted at all, protection has depended on the traditional doctrine that laws of a foreign sovereign deemed confiscatory will be denied effect as against the public policy. In Plesch et al.v. Banque Nationale

an Accessions Tax, 1 TAx L. Rev. 25 (1945) ; Lowndes, Tax Awoidance and the Fadcral Estate Tax, 7 IAW \& Contexr. Prob. 309, 328 (1940).

* Plesch et al. v. Banque Nationale de la Republique D'Haiti, 298 N.Y. 573, S1 N.E. 2d 106 (1948).

1. Aliens may be classified broadly as friendly-"... the subject or citizen of a foreign government at peace with our own"-or as enemy- ". . . the subject or citizen of some hostile state or power." Black's Law Dictronary 91 (3rd ed. 1933).

2. Id. at 396, defines "confiscate" as "[t]o appropriate property to the use of the state" See Ware v. Hylton, 3 Dall. 199, 234 (U.S. 1796).

Confiscation might be distinguished from appropriation and nationalization by the absence of compensation, but inadequate compensation would seem to amount, in effect, to confiscation, and will be so considered herein.

For a general treatment of the subject see HollandER, Cosifischtion, Aggressio: AitD Foreign Fund Control in Axrerican Law (1942) passim.

3. Almost without exception litigation has been confined to New Yorls courts. HoLLANDER, op. cit. supra note 2, at 7. See also N. Y. Crvir Practrce ACT, \$977-b, specifying means of appointing a receiver of assets in New York of nationalized forcign corporations, and of distribution of those assets to creditors.

4. "It is a well-settled principle ... that if the enforcement of the foreign right is contrary to the public policy of the forum, or place where enforcement is sought, the person claiming under the foreign law will lose" GoopkicB, Confluct of Laws 14 (2d ed. 1938); Restateasent, Conflict of Laws $\$ 612$ (1934). However, the same principle does not apply to orders of confiscation by a sovereign of property coltolly within its own borders. Oetgen v. Central Leather Co., 246 U.S. 297 (191S); Underhill v. Hernandez, 168 U.S. 250 (1897). Where no policy of the forum conflicts foreign laws are ordinarily given effect as a matter of comity. "Comity may be defined as that reciprocal courtesy which one member of the family of nations owes to the others. ... It assumes the prevalence of equity and justice" Russian Socialist Federated Soviet Republic v. Cibrario, 235 N.Y. 255, 258, 139 N.E. 259,260 (1923). 
de la Republique D'Haiti ${ }^{5}$ the doctrine was used to deny effect to vesting decrees of Haiti which, purporting to be part of a pattern of enemy alien legislation, ordered seizure of securities in New York belonging to a stateless person domiciled in Haiti. The court refused, in the absence of proof that the decrees comported with New York public policy, to assume that they were valid, and found that the state-controlled bank which had effectuated this appropriation might be sued for conversion. ${ }^{6}$

In that it poses only an issue of due process uncomplicated by elements of extrinsic political policy, the Plesch decision looks for precedent directly to the early cases arising out of Soviet Russian nationalization decrees. There the courts' refusal to allow confiscation of private Russian assets in New York depended simply upon a finding that the Soviet rescripts were repugnant to basic American public policy requiring due process of law and to the demands of equity and justice. ${ }^{8}$ The refusal of the Federal government to recognize the Soviet served merely to reinforce the courts' disapproval of the decrees. ${ }^{9}$

Considerations of political expendiency first began to outweigh the due process test after the executive branch granted recognition to the Soviet Union in $1933 .{ }^{10}$ The recognition was accomplished by an exchange of

5. 298 N.Y. 573, 81 N.E.2d 106 (1948), affirming, per cutriam, 77 N.Y.S.2d 43, 273 A.D. 224 (1948), which reversed order vacating a warrant of attachment, 77 N.Y.S.2d 41 (Sup. Ct. 1948).

For a related case see Republic of Haiti v. Plesch et al., 190 Misc. 407, 73 N.Y.S.2d 645 (Sup. Ct. 1947), wherein a counterclaim filed by Plesch in a suit by the Haitian Government for a declaratory judgment as to its rights in certain securities was dismissed as introducing new matter into a suit initiated by a sovereign.

6. Defendant Bank's defense that it had acted pursuant to governmental orders was unsuccessful, the court holding that those orders were ineffective. Plesch et al. v. Baniule Nationale etc., 77 N.Y.S.2d 43, 47. See Little v. Barreme, 2 Cranch 170 (U.S. 1804).

7. There is no apparent affirmative United States political policy indicated in the opinion of the Appellate Division countervailing considerations of due process.

8. Vladikavkazsky Railway Co. v. New York Trust Co., 263 N.Y. 369, 189 N.E. 456 (1934); Petrogradsky M.K. Bank v. National City Bank, 253 N.Y. 23, 170 N.E. 479 (1930), cert. dented, 282 U.S. 878 (1930); Joint Stock Co. v. National City Bank, 240 N.Y. 368, 148 N.E. 552 (1925) ; Russian Reinsurance Co. v. Stoddard, 240 N.Y. 149, 147 N.E. 703 (1925). "[T]he American courts, like the English courts, have refused to admit, as contrary to public policy, the validity of the Soviet decrees in changing the title to property in the United States, and have in fact gone out of their way to let the old directors or stockholders sue American banks or other debtors to recover the assets of the liquidated corporations." Borchard, Confiscations: Extraterritorial and Domestic, 31 Anr. J. INT't L. 675, 678 (1937). See, Connick, The Effect of Soviet Decrees in American Courts, 34 Y L. J. 499 (1925) ; Comment, 17 ST. JoHN's L. Rev. 20 (1942).

9. For a summary of the United States attitude towards Russia prior to recognition see Recognition of Russia, 28 AM. J. INT'L L. 90 (1934).

10. Dep't State Eastern European Series No. 1, Establishment of Diplonatic Relations With the Union of Soviet Socialist Republics (1933). Prior to recognition the Soviet government was not recognized as a party in our courts. Russian Socialist Federated Soviet Republic v. Cibrario, 235 N.Y. 255, 139 N.E. 259 (1923) (unrecognized foreign sovereign may not sue in our courts as plaintiff) ; cf. Wulfsolin v. R.S.F.S.R., 234 
letters granting, on our part, recognition to the Soviet regime and receiving in return an assignment (the Litvinoff Assignment) to our government of all claims asserted by the U.S.S.R. against Americans.11 Apparently no consideration was given to the possible effects of such an arrangement upon pre-existing legal doctrines of property. ${ }^{12}$ Thereafter the due process test was held to give way to the superior effect of this "international compact" 13 and the court was placed in the position of having to reconcile the wellfounded American conflicts of law rules against enforcement of foreign confiscatory laws with this apparent official acceptance of Soviet nationalization.

In United States v. Belmont 14 the Presidential act of recognition was interpreted to have validated the Soviet decrees in our courts, at least when the confiscation was of the deposit of a Russian company made with a private New York banker. ${ }^{15}$ This decision was soon over-shadowed by the sharply criticized case of United States v. Pink. ${ }^{10}$ New York's due process

N. Y. 372, 13\& N.E. 24 (1923), appeal denied, per curiam, 266 U.S. 580 (1924) (forcign sovereign, even though unrecognized, cannot unwillingly be sued).

11. The Soviet agreed that "... preparatory to a final settlement of the claims and counterclaims between the Governments of the Union of Soviet Socialist Republics and the United States of America and the claims of their nationals the Government of the Union of Soviet Socialist Republics will not take any steps to enforce any decisions of courts or initiate any new litigations for the amounts admitted to be due or that may be found to be due it, as the successor to prior Governments of Russia, or otherwise, from American nationals, ... and will not object to such amounts being assigned and does hereby release and assign all such amounts to the Government of the United States, ... [the U.S.S.R.] to be duly notified ... of any amount realized by the Government of the United States from such release and assignment." Dep'r State Eastern Europens Series No. 1, op. cit. supra note 10, at 13 .

12. There is no evidence in the exchange of letters between President Roosevelt and MIr. Litvinoff that attempts would be made to reconcile the Soviet attitude tovards proparty with our own. Dep't State EAstern Europens Sertes No. 1, op. cit. supra note 10. See Borchard, Shall the Executive Agrecntent Replace the Troaty, 3S Ass. J. I:ir'L L. 637 (1944).

13. United States v. Belmont, 301 U.S. 324, 327 (1937). It was held that by receiving assignment of Soviet claims against Americans the United States had, by virtue of the reeognition, validated all acts of the Soviet Union from its inception. New Yorl: public policy repudiating confiscation could not stand against a national determination of what our foreign relations were to be. See Jessup, The Litvinoff Assigmment and the Bclmont Casc, 31 AN. J. INT'L L. 481 (1937).

14. 301 U.S. 324 (1937).

15. "The curious result of the Belmont opinion is that the Sovict confiseatory decrees are given extra-territorial effect in the United States-although not in any other countrywhereas the contention that this confiscation violates Article 5 of the Constitution of the United States is met by the answer that 'our Constitution, laws and policies have no extraterritorial operation unless in respect to our own citizens." " Borchard, Confiscations: Extraterritorial and Domestic, 31 Axr. J. INr'L L. 675, 676 (1937). The Court found no question regarding the Fifth Amendment involved, with only the rights of a Russian corporation to confiscated property in dispute.

16. 315 U.S. 203 (1942). "[T] he court has upset and parted with international law, as heretofore understood, gravely impaired or weakened the protection to private property af- 
standard was held to have been superseded by a national policy giving effect to the Soviet seizures of Russian citizens' private property, and on the assumption that no citizens of this country were involved as contesting creditors the Court granted to the United States, as assignee of the Soviet claims, the American-held assets. ${ }^{17}$ Thus the nationally instituted policy towards Russia, rather than the previous tests of conformity with due process became decisive and weakened the protection accorded alien holdings. ${ }^{18}$

During World War II overriding considerations of economic warfare influenced judicial disposal of alien property. Not only were foreign funds under the strict control of the Alien Property Custodian, ${ }^{19}$ but the prospects of their release were considered a matter to depend primarily upon military

forded by the Fifth Amendment of the United States Constitution, endowed a mere exect: tive agreement by exchange of notes with the constitutional force of a formal treaty, mig: construed the agreement, and, it is respectfully submitted, confused that foreign policy of the United States in whose alleged support this revolutionary decision was thought necessary." Borchard, Extraterritorial Confiscations, 36 Axr. J. INT'L L. 275 (1942). "It is probably no exaggeration to say that the principle that confiscatory legislation is denied any effect upon property situate outside the boundaries of the confiscating state, has hitherto been regarded as one of the most securely established and most commonly accepted maxims of international law .. ." 5 Mop. L. REv. 262 (1942). Jessup, The Litvinoff Assignment and the Pink Case, 36 AMr. J. INT'亡 L. 282 (1942) ; Note, 51 Yale L. J. 848 (1942). Bul cf. Note, 48 Cor. L. REv. 890 (1948) reappraising the case and finding it less "revolutionary" than earlier commentators had predicted.

17. The rationale of the opinion appears to be one of validating the means adopted by the federal government to secure for the United States and its citizens settlement of claims against Russia through acquisition of Russian assets located here prior to settlentent of those claims held by foreigners against the assets. The Court admitted evidence that the Soviet confiscations were intended to have extraterritorial effect, hence bringing the New York property of the Russian insurance company in question within the scope of the Litvinoff Assignment. Borchard questions whether the original intent of the Soviet confiscations was to reach property in the United States, and whether the Litvinoff Assignment purported to convey such private property to the United States. Borchard, Confiscations: Ex. traterritorial and Domestic, 31 AMr. J. INTL L., 675, 677 (1937). And see, Jessup, Has the Supreme Court Abdicated One of its Functions, 40 AM. J. INT'L L. 168 (1946).

18. For the varying judicial attitudes compare: Vladikavkazsky Ry. Co. v. New York Trust Co., 263 N.Y. 369, 189 N.E. 456 (1934) (recognition affords no controlling reason for enforcement of repugnant foreign decrees) ; United States v. Belmont, 301 U.S. 324 (1937) (recognition validated Soviet decrees and assignment of her claims took precedence over state policies); Guaranty Trust Co. v. United States, 304 U.S. 127 (1938) (United States as assignee of Soviet stood in no better position as to claims barred by statute of limitations) ; Moscow Fire Insurance Co. v. Bank of New York and Trust Co, 280 N.Y. 286, 20 N.E.2d 758 (1939) (Soviet decrees not intended to apply extraterritorially), aff $d$ by equally divided court, 309 U.S. 624 (1939) ; United States v. Pink, 315 U.S. 203 (1942) (United States was assignee of Soviet claims under decrees intended to have extraterritorial effect on assets in New York).

19. Executive Order 8389, April 10, 1940 froze assets of citizens of Norway and Denmark. As the war spread controls were extended. UNITEd States Trensury Dep'T, Documents Pertanning to Foreign Fund Control (1945). For comprehensive discussions of the wartime regulation of enemy alien property, see Domke, The Cantrol of Alien Property (1947); Dodike, Trading With the ENeny in World War II (1943); 11 Law and Contensorary Problems No. 1 (1945). See notes 26, 27, infra. 
expediency. ${ }^{20}$ A Vichy French decree was deemed "penal" and therefore ineffectual in confiscating property for non-compliance with a citizenship order, ${ }^{21}$ whereas a decree of the Netherlands government-in-exile was applied on the grounds that it was conservatory in that it kept assets out of enemy hands. ${ }^{22}$ The only indication of a possible post-war reemergence of the due process standard was in a decision refusing to accept as valid in our courts Soviet confiscations of Estonian property. ${ }^{23}$

The cases thus demonstrate a generally consistent pattern of judicial adherence to the changing policies of the executive. Where no national policy is evident the courts will shield the alien; where the executive demonstrates some sympathy towards the aims of the foreign government the shield will be lowered. That such judicial obedience is either desirable or necessary seems open to serious question.

In international law it is basic doctrine that foreigners shall receive, in general, the same treatment and rights accorded to citizens. ${ }^{24}$ Although the concept has frequently been treated as a vague moral tenet subject to interpretation by the individual sovereign, its inclusion in our due process pattern has become sufficiently fixed that the $P$ ink decision aroused wide resentment as an infringement of essential rights. ${ }^{25}$

Maintenance of a due process standard need not preclude enforcement of reasonable measures taken by foreign governments to secure or control all available funds. ${ }^{26}$ Due process might be held satisfied by a foreign decree

20. "A primary aim of the freezing control was to prevent nationals of the invaded countries of Europe from being despoiled and forced under duress to transfer to the Axis powers their claims to American assets. The freezing controls also served in many ways as a weapon of economic warfare to hamper the financial and commercial activities of our World War II enemies." Treasury Department press release, Sept. 30, 1948, reported in 19 Dep't State Bull. 472 (1948).

21. Bollack v. Societe Generale Pour Favoriser etc., 33 N.Y.S.2d 985 (1942); 17 Sr. JoHs's L. REv. 20, 25 (1942). "It is well-settled in common law jurisdietions that the courts of one state do not enforce claims arising under the penal laws of another." GoovRICH, CONFLICT OF LAWS 16 (2d ed. 1938).

22. Anderson v. Transandine Handelmaatschappij, 289 N.Y. 9 (1942). The limits of this case as precedent, however, appear narrow, since much importance was attached to a letter from Secretary of State Hull filed for the Department of State approving the decree in question. Id. at 17. See Note, 41 Cor. L. REv. 1072 (1941).

23. A/S Merilaid \& Co. v. Chase National Bank of City of Nev York, 189 Mise. 285, 71 N.Y.S.2d 377 (Sup. Ct. 1947), wherein the court distinguished United States v. Belmont, 301 U.S. 324 (1937) and United States v. Pink, 315 U.S. 203 (1942) as arising under the Litvinoff Assignment, not applicable here.

24. 4 MOORe, International LAw Digest $\$ \$ 534-6$ (1906); Kohler, Legal Disabilitics of Aliens in the United States, 16 A.B.A.J. 113 (1930). "A corporation organized and existing under the laws of a foreign state which we have recognized and with which we live in comity may ordinarily seek the aid of our courts in the assertion of its rights, even against our own citizens." Russian Reinsurance Co. v. Stoddard, 240 N.Y. 149, 154, 147 N.E. 703, 704 (1925).

25. See note 16 , stipra.

26. Prior to World War II the property of friendly aliens had been generally free from restrictions, either by home governments or by our own. However, with the cessation 
providing for compensation in domestic bonds, or for a choice of domestic investments, or for deferred payment of compensation providing the terms were equitable. ${ }^{27}$ Facilitation of international payments may require such adjustments. It does not seem, however, to compel a denial to aliens of the substance of due process.

In the immediate future the courts may have to face the question squarely in the context of the current national policy of the Marshall Plan. The Foreign Assistance Act of $1948{ }^{28}$ provides that participating countries shall take measures to locate and employ "to the extent practicable" ${ }^{29}$ the assets of their citizens which are situated in America. No further elaboration of

of hostilities in World War II most Western European nations continued controls or reenacted new ones aimed at marshalling all available wealth for reconstruction. In general, Western European nations have placed all transactions involving foreign exchange and dealings in assets abroad under government supervision. In the Netherlands, pursuant to Royal Decree of October 10, 1945 (State Law Record F 222) De Nederlandsche Bank N.V. has been designated as the authority with control over all aspects of foreign fund regulation. Transactions involving foreign exchange must be licensed, and all forcign exchange must be offered for sale to the Bank, in return for guilders, as must the proceeds from other assets. Communication to the Yale Law Journal from Financial Counsclor, Netherlands Embassy, Oct. 4, 1948, in the Yale Law Library. Liquidation and requisitioning of securities have been undertaken, to supplement income from abroad. N.Y. Times, Feb. 23, 1948, p. 29, col. 7; N.Y. Times, March 8, 1948, p. 27, col. 4; and for a list of called securities, N.Y. Times, March 20, 1948, p. 23, col. 7.

For Belgium substantially similar restrictions have been imposed; disclosure of foreign assets was ordered, but liquidation and surrender of assets has not been requested, and disposition of such assets is subject to the authority of the Institut Belgo-Luxembourgeois du Change. Communications to the Yale Law Journal from Belgian Embassy, Scpt. 28, 1948; Nov. 24, 1948, in the Yale Law Library.

The United Kingdom, likewise, has adopted a framework of regulation, requiring sale of all foreign currencies to His Majesty's Treasury, and placing comprehensive controls on dealings in securities under the provisions of the Exchange Control Act, 1947. 10 \& 11 Gะo. 6. Dollar securities were required to be registered and the Treasury given power to vest ownership of certain ones in time of need. Communication to Yale Law Journal from United Kingdom Treasury Delegation, Oct. 6, 1948, in the Yale Law Library.

France has required deposit of certain foreign securities held in France, and conversion of securities held abroad. DeCrEe No. 48-178, Feb. 2, 1948; DECREE No. 48-393, March 8, 1948. (Belgian, Dutch, British and French laws are herein reported from information received in communications to the Yale Law Journal from the respective embassies. Citations are included where given.)

27. Compensation in domestic currencies is being paid by European nations for those foreign assets and exchange which they require to be made available to the government. The equivalent amounts in domestic currencies, i.e., sterling, guilders, francs, at the official exchange rate has been the usual compensation. Communication from United Kingdom Treasury Delegation; Communication from Financial Counselor, Netherlands Embassy; supra, note 26. The basis of French compensation is set forth in an Informal Translation, Notice 305 of Office des Changes. Communication to Yale Law Journat from Financial Attache, French Embassy, Nov. 15, 1948, in the Yale Law Library.

28. Pub. L. No. 472, 80th Cong., 2d Sess., (April 3, 1948).

29. Id. at $\S 115$ (b) (4). The National Advisory Council has opposed as "unwise" the forced liquidation of assets as a condition to Marshall Plan aid. Letter from Secretary Snyder to Senator Vandenberg, N.Y. Times, Feb. 3, 1948, p. 1, col. 6. 
this requirement has been made in the agreements which have been signed. is In the transition from war-time controls of foreign funds the United States has required certification by the home government before releasing these assets. $^{31}$ Thus aliens seeking the use of their property have had, in effect, to disclose its existence and extent to their governments and thereby place themselves within the controls and pressures that may be exerted upon them at home. It is through the extension of these foreign regulations to property in the United States that the due process issue may come to the forefront.

The issue could be pretermitted entirely by the insistence of the executive on reasonable compensation in foreign property appropriations. To date, however, there is no indication that the government has taken notice of the due process problem inherent in the utilization by Marshall Plan participants of assets held abroad by private citizens.

Should foreign vesting decrees force the due process issue in American courts, judicial sympathy with the aims of the Marshall Plan, together with the precedent of the $P$ intk case, might well be sufficient for their enforcement, even if they were confiscatory in nature. While Europe struggles desperately to rebuild its economy, with success in large measure depending upon the availability of dollar exchange, its own nationals, vith varying motives, maintain much badly needed private capital out of reach in the United States. Alien holdings in this country have been estimated at between $\$ 4,900,000,000$ and $\$ 5,400,000,000 .^{32}$ There are indications that

30. "[There will be adopted by the Government of Italy] . . . [t]o the estent practicable, measures to locate, identify, and put into appropriate use in furtherance of the joint program for European Recovery assets, and earnings therefrom, which belong to nationals of Italy and which are situated within the United States of America, its territories or possessions. Nothing in this clause imposes any obligation on the Government of the United States of America to assist in carrying out such measures or on the Government of Italy to dispose of such assets." Text of Economic Cooperation Agrcennent arilh Italy, 19 DEp'x State BuLl. 38, 39 (1948). The agreements with all participating countries are expected to be closely similar. Id. at 37 .

31. For the liquidation program, see letter from Secretary Snyder to Senator Vandenberg, sitpra, note 29 . In releasing assets blocked here the Treasury has required certification by the home governments for amounts over $\$ 5000$, and the names of direct holders who do not obtain release of their assets will be disclosed to the government coneerned, ". . . in order effectively to help the recipient countries obtain control of the blodied assets of their resident citizens." These measures were not to be applied to $\$ 4,300,000,000$ in "free" assets "because the amounts of such assets which are unlonown to the governments of recipient countries are probably insignificant;" so that this liquidation procedure vas applied only to $\$ 1,100,000,000$ of assets remaining blocked. Id. The Treasury Department has turned over final disposition of alien property to the Department of Justice. Executive Order 9989, 13 FED. REG. 4891 (1948).

32. Letter from Secretary Snyder to Senator Vandenberg, suspra, note 29, estimating free private assets at $\$ 4,300,000,000$ and those remaining blocked at $\$ 1,100,000,000$. For the lesser estimate see Departarent of State, Outhine of Europensi Recovery Progrars 103 (1948). The most comprehensive analysis of the extent of foreign-owned assets in the United States is contained in the Treasury Departarent, Census of Fonergi-Owried AsSETS IN THE UNITED STATES (1945), compiled from information submitted by banlis, corporations and individuals on Form TFR-300 at the start of World War II. Assembled 
many alien-owned assets are hidden, ${ }^{33}$ and that the flight of foreign capital continues today. ${ }^{34}$ Courts might plausibly conclude that for the moment, at least, protection of such private property constitutes an unwarranted hindrance to the rebuilding of those very nations on which we depend to defend private property throughout the world.

But the price eventually paid for expediency in meeting the dilemma posed by considerations of due process on the one hand and purported political and economic necessity on the other might be out of proportion to the gains. The gains lie in the saving to the Marshall Plan nations, in that no diversion of taxes or monetary inflation would be required to pay off their nationals for their foreign held assets. But while these savings would be significant in terms of the foreign currencies, such currencies could not, in any event, be of assistance to them in their most pressing need-credit with which to purchase scarce goods and materials from the hard currency countries. The saving allowed would not seem to be crucial to the success of the Marshall Plan. But the losses involved might in the long run be more serious. So long as the American Constitution continues to protect the private property of its citizens and established law declares that aliens are entitled to equal rights with them, and so long as our foreign policy continues to support the concept of private property, the enforcement of confiscatory laws on the ground that the promulgating nations are friendly will smack of opportunism. In what is not least of all a struggle of ideas, the maintenance of ideological integrity may finally be the most expedient of policies.

for purposes of wartime controls, it is highly inaccurate as a measure of such assets as they exist today.

33. "In many instances these assets and their owners are not known to the forcign governments." Department of State, op. cit. supra, note 32. See, N.Y. Times, March 1, 1948, p. 28, cols. 4, 6. But of. letter from Secretary Snyder to Senator Vandenberg, supra, notc 31. It is, of course, difficult to ascertain the extent to which the holdings of aliens are in the hands of dummy corporations, American corporations or citizens.

34. This is evidenced by the continued success of black market operations in forcign exchange carried on in most European nations. See N.Y. Times, Feb. 4, 1946, p. 28, col. 4 ; N.Y. Times, January 29, 1948, p. 1, col. 2; N.Y. Times, July 9, 1948, p. 6, col. 4. Smuggling of diamonds, gold and exchange constitutes another device for avoiding the regula* tions. N.Y. Times, July 22, 1946, p. 30, col. 6; N.Y. Times, Oct. 6, 1948, p. 1, col. 2. 